\title{
A new species of Temelucha Förster from Malta with an updated and revised identification key to the Western Palaearctic Temelucha species (Hymenoptera, Ichneumonidae, Cremastinae)
}

\author{
Zoltán Vas' \\ I Hungarian Natural History Museum, Department of Zoology, Hymenoptera Collection, H-1088 Budapest, \\ Baross Street 13, Hungary \\ Corresponding author: Zoltán Vas (vas@nhmus.hu) \\ Academic editor: G. Broad | Received 5 October 2015 | Accepted 11 December 2015 | Published 1 March 2016 \\ http://zoobank.org/FEAF7AC2-9D81-430E-A1CF-0A76752E132E \\ Citation: Vas Z (2016) A new species of Temelucha Förster from Malta with an updated and revised identification key \\ to the Western Palaearctic Temelucha species (Hymenoptera, Ichneumonidae, Cremastinae). Journal of Hymenoptera \\ Research 48: 67-84. doi: 10.3897/JHR.48.7094
}

\begin{abstract}
A new species, Temelucha rea sp. n., of the ichneumon wasp subfamily Cremastinae is described from Malta. Since the last published keys to the Western Palaearctic species of Temelucha are outdated and lack several species, an updated and revised identification key is provided for the 47 known Temelucha species of the region.
\end{abstract}

\section{Keywords}

Taxonomy, species description, ichneumon wasp, Mediterranean region, Europe

\section{Introduction}

Temelucha Förster, 1869 is a moderately species-rich genus of the ichneumon wasp subfamily Cremastinae. The definition of the genus was summarized by Townes (1971). According to Yu et al. (2012), 235 valid species belong to this genus, with worldwide distribution, and 46 species have been known from the Western Palaearctic region. The 
early keys provided for the Western Palaearctic species of Temelucha (i.e. in combination with Cremastus Gravenhorst, 1829 at that time) are seriously outdated by now and cover only a very limited set of species (e.g. Szépligeti 1905, Schmiedeknecht 1910). The only comprehensive taxonomic revision of the European species was published by Šedivý (1971). In his work he not only provided a useful key for the 23 European Temelucha species known at that time but also gave detailed descriptions for all the species. As several, previously described species were published with insufficient morphological descriptions, Šedivy's (1971) work is still a base-line for the European species.

Since Šedivýs (1971) revision, several new species have been described from the Western Palaearctic region, mainly from the Balkan Peninsula and the Mediterranean area (Aubert 1977, 1981, Narolsky 1987, Kolarov 1989, Šedivý and Schwarz 1993, Kolarov 1995, 1996, Kolarov and Beyarslan 1999, Narolsky 2004). Kolarov (1997) provided a new key for 36 species of the region with a valuable zoogeographical discussion. His key includes many but not all species that have been described since Šedivý (1971) and it was a good attempt to simplify the distinguishing characters; however, some mistakes could be revealed by comparing the distinguishing characters of some species in that key with the original descriptions and type specimens (e.g. a species known only from males could only be keyed out by choosing between ovipositor characteristics, or a species with a yellow scutellum was keyed in the section of species with a black scutellum, etc.). Additionally, some species described long ago, such as Temelucha corsicator Aubert, 1961, T. picticollis (Hellén, 1949), and T. minuta (Morley, 1912) were included in neither previous key.

Recently, by finding a new Temelucha species from Malta, I realized the necessity of an updated identification key which covers all the species of the region and corrects the errors of the previous keys. In this paper, along with the description of a new species, an identification key is provided for the 47 currently known Western Palaearctic Temelucha species (including the one described here).

\section{Methods}

Ichneumonidae taxonomy and nomenclature follow Yu and Horstmann (1997) and Yu et al. (2012). The morphological terminology follows Gauld (1991), and Gauld et al. (1997). The updated and revised key is based on previous keys (Šedivý 1971, Kolarov 1997), original descriptions and descriptions given by Šedivý (1971), Narolsky (1990), Kolarov and Beyarslan (1999), Kolarov and Yurtcan (2009), and Rousse et al. (2011). The key was tested on the material of the Hungarian Natural History Museum (HNHM), Budapest. The author examined the types of species described by Szépligeti (deposited in HNHM), and of T. picticollis (Hellén) (borrowed from the Finnish Natural History Museum, Helsinki). Distribution notes are not given in the key; it would just repeat Kolarov's (1997) work, and are well summarized in Yu et al. (2012). The specimens were examined using Nikon SMZ645 and Olympus SZX9 stereoscopic microscopes. Photos were taken by T. Németh (HNHM Coleoptera Col- 
lection) with Nikon D5200 and Nikon AF Micro Nikkor 60mm lens and Mitutoyo M Plan Apo 5X microscope lens. Exposures were stacked in Zerene Stacker, post image work was done with Photoshop CS5.

\section{Results}

\section{Taxonomy}

\section{Temelucha rea sp. n.}

http://zoobank.org/349622C9-A95A-426A-9B02-27207B713487

Material examined. Holotype: female, Malta, Mellieha, Il-Prajjet, 14.viii.2014, leg. M. Zammit. Paratype: female, same locality, collecting date, and collector. The holotype and the paratype are deposited in the HNHM Hymenoptera Collection (HNHM Id. No. 23011, 23012, respectively).

Diagnosis. The new species belongs to the morphological group of Temeluch a species with the following characters in combination: mainly yellow head and thorax, at least the basal part of the hind coxa dark, the second discal cell more than $1.5 \times$ as long as the first sub-discal cell, and the second recurrent vein $(2 m-c u)$ postfurcal. Within this group it most resembles T. decorata (Gravenhorst, 1829) due to its colour pattern; however, it is significantly smaller than $T$. decorata. Another such small species within this group is T. picticollis (Hellén, 1949); however, T. picticollis differs from the newly described species by its black propodeum, the absence of notauli, and colour pattern.

Description. Female (holotype) (Figs 1-4). Body length $4.7 \mathrm{~mm}$, fore wing length $2.7 \mathrm{~mm}$, ovipositor sheath $2.0 \mathrm{~mm}$.

Head. Antenna with 26 flagellomeres. First flagellomere $3.3 \times$ as long as wide. Gena short, strongly constricted behind eyes. Occipital carina dorsomedially incomplete. Occiput smooth and shiny. Vertex, frons, gena and malar space finely coriaceous. Middle of face punctate, punctures separated from each other by usually less than a puncture diameter. Clypeus with fewer punctures, convex in profile, and with curved apical margin. Inner eye orbits parallel. Ocellus diameter slightly smaller than distance between lateral ocellus and eye. Malar space about $0.75 \times$ as long as basal width of mandible. Mandibular teeth of equal length.

Mesosoma. Mesosoma densely punctate; distance between punctures on mesonotum and mesopleuron generally smaller than puncture diameter. Pronotum less densely punctate and with fine wrinkles. Epomia distinct. Notaulus distinct, reaching middle of mecoscutum. Scutellum punctate with lateral carinae not reaching its middle. Sternaulus indistinct. Speculum shiny and almost impunctate. Epicnemial carina present, reaching above middle of hind edge of pronotum. Posterior transverse carina of mesosternum complete. Metanotum (including postscutellum) with longitudinal wrinkles and a few punctures. Metapleuron densely punctate. Legs slender, hind femur about $5 \times$ as long as wide. Tarsal claws small and thin, only slightly longer than aro- 

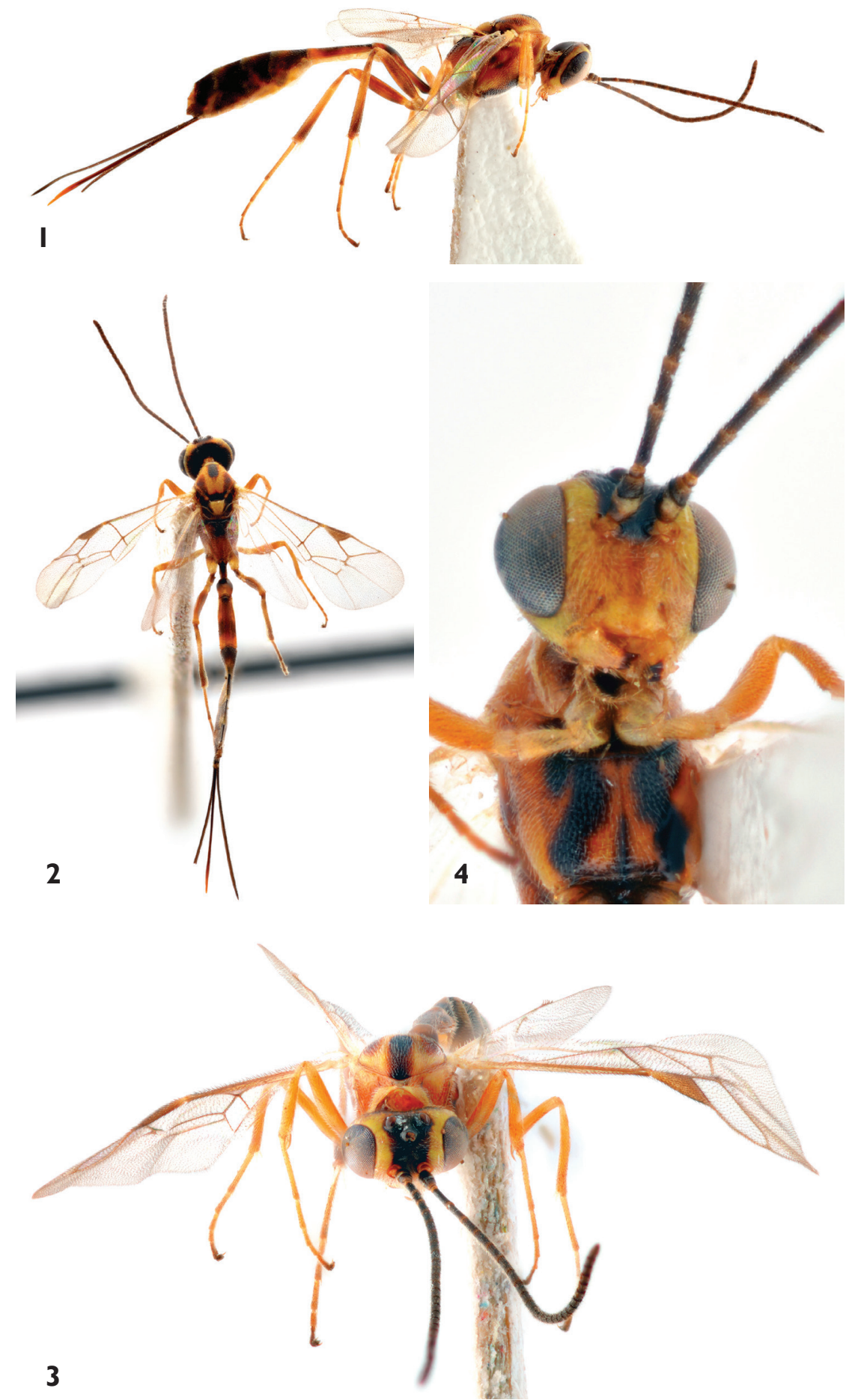

Figures I-4. Holotype of Temelucha rea sp. n., female. I lateral view $\mathbf{2}$ dorsal view $\mathbf{3}$ frontal view 4 anteroventral view. 
lium. Propodeum long, only very weakly convex in profile with its apical edge reaching middle of hind coxa. Pleural carina complete, its distance from circular propodeal spiracle about equal to diameter of spiracle. Spiracle connected to pleural carina by a raised ridge. Lateromedian and lateral longitudinal carinae and basal transverse carina complete. Median section of apical transverse carina indistinct. Pleural areas strongly punctate. Lateral areas with dense punctures and sparse transverse wrinkles. Area basalis very small with almost parallel lateral carinae on its basal half. Area superomedia and area petiolaris indistinctly separated; both areas narrow, almost parallel-sided and with dense transverse striation, except basal part of area superomedia, which is almost triangular-shaped and less striate, rather shiny with a few punctures.

Wings. Wing membrane with dense short hairs. Fore wing with vein $c u$ - $a$ interstitial. Vein $2 m-c u$ postfurcal with a wide bulla. Distal abscissa of $R s$ almost completely straight. Second discal cell about $2 \times$ as long as first sub-discal cell (measured at front margins). Pterostigma slightly shorter than front margin of marginal cell. Hind wing with vein $c u-a+$ abscissa of $C u 1$ between $M$ and $c u-a$ almost straight, not intercepted. Distal abscissa of $C u 1$ spectral.

Metasoma. First metasomal segment slightly longer (about $1.15 \times$ ) than second segment. Ventral margins of first tergite touching each other ventrally. Lateromedian carinae of first tergite relatively weak. Second tergite with longitudinal striation characteristic of many Cremastinae. Third tergite coriaceous. Following tergites mainly punctate. Metasoma strongly laterally compressed, especially from third tergite on. Ovipositor sheath twice as long as hind tibia (or as long as fore wing from base to middle of marginal cell). Ovipositor straight, laterally compressed with distinct subapical notch. Apex smooth and straight, with subapical part somewhat widened in profile.

Colour. Head yellow except following parts. Upper face with brownish patch in midline. Black parts are: mandible teeth, middle of frons, ocellar area, posterior half of gena and occiput. Maxillary and labial palpi yellowish brown. Antennal flagellomeres dark brown with lighter apical bands on first few basal flagellomeres. Scapus and pedicellus mainly dark brown with some yellowish brown colouration on ventral side. Wings hyaline, venation and pterostigma brownish. Pronotum reddish with wide yellowish edges and hind corner. Mesoscutum yellow with an anteromedian black patch and two posterolateral brownish patches. Hind edge of mesoscutum and scutellar groove black. Scutellum entirely yellow. Mesopleuron mainly reddish and yellowish with black patches on ventral parts. Metanotum dark brown, its center somewhat lighter reddish brown. Metapleuron reddish and yellowish, its anterior ventral corner black. Propodeum almost entirely pale reddish, only basally black, medially reaching only basal part of area superomedia.

Fore and mid legs: coxae yellow with brownish patches basally; trochanters and trochantelli yellow; femora, tibiae and tarsomeres pale reddish except brown apical tarsomeres. Hind leg: coxa basally black; trochanter and trochantellus brown with yellowish apical parts; femur brown, basally and apically yellowish brown; tibia yellowish brown in middle, basally and apically brown; tarsomeres brown with yellowish brown base of first tarsomere; apical tarsomere dark brown. 


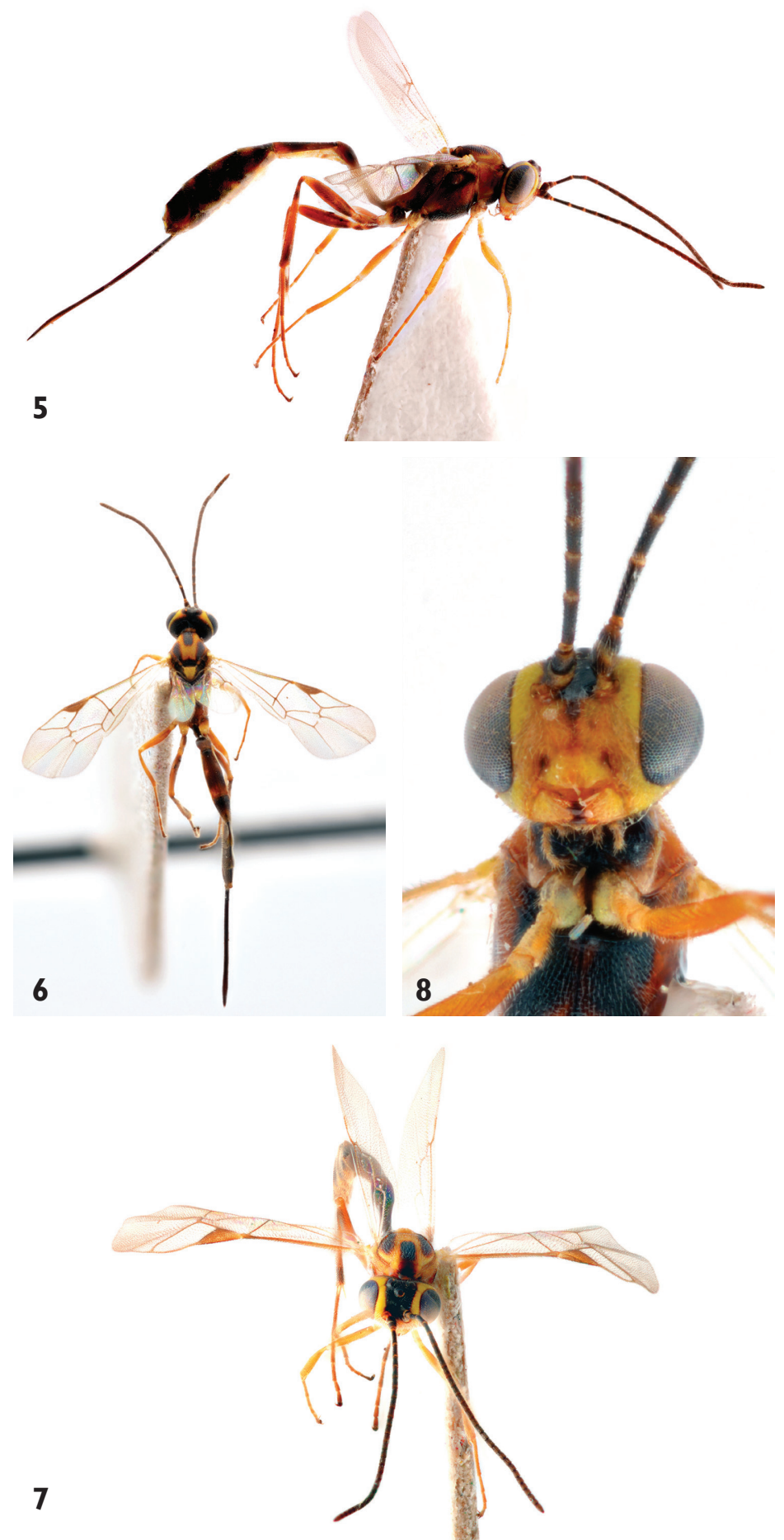

Figures 5-8. Paratype of Temelucha rea sp. n., female. 5 lateral view $\mathbf{6}$ dorsal view $\mathbf{7}$ frontal view 8 anteroventral view. 
First tergite reddish brown laterally as well as dorsally in middle and in most apical part. Basal part of tergite and basal part of postpetiolus almost black dorsally. Second tergite reddish brown with irregular brown patches in middle. Following tergites dark brown (almost black) basally, reddish brown apically with yellowish brown lateral and posterolateral edges. Ovipositor sheath dark brown (almost black); ovipositor reddish brown with paler apex.

Variation. The paratype female (Figs 5-8) is identical to the holotype in all the characteristics described above except that it is darker than the holotype. The brownish patch in the midline of the upper face is larger and black; pronotum more reddish; the posterolateral dark patches of the mesoscutum are black; mesopleuron with less yellowish and more reddish colouration and almost black around the speculum; metanotum almost black; propodeum darker, the basal half black, apical half pale reddish; hind tibia darker brown in the middle; the first and second tergites are darker, the light edges of the apical tergites are slightly darker.

Male. Unknown.

Distribution. Currently known only from Malta.

Ecological note. Adult wasps emerged on 14.viii.2014 from flowers of Limbarda crithmoides (Linnaeus) collected on 8.ix.2014. Several adult moths of Eublemma parva (Hübner) (Lepidoptera: Noctuidae) also emerged from the flowers; most probably it is the host species.

Etymology. Arbitrary combination of letters, feminine gender.

\section{Identification key to Temelucha in the Western Palaearctic region}

Supporting but not distinguishing characters are given in parentheses, comments in brackets. Figures 9-18 depict some important characteristics. Only some specific figures are cited in the key; other features used throughout the key such as ovipositor (Figs 9-11) and propodeum (Figs 14-15) shapes are recommended to be checked before using the key.

1 First tergite $0.6-0.8 \times$ as long as second tergite (ovipositor apex down-curved; male ocellus relatively small, its diameter about as long as distance between lateral ocellus and eye; body length $-6 \mathrm{~mm}$ )

T. brevipetiolata Kolarov, 1989

- $\quad$ First tergite as long as or longer than second tergite

.2

2 Malar space at least $2 \times$ as long as basal width of mandible (ventral margins of first tergite not touching each other; ovipositor sheath about as long as fore wing; ovipositor apex straight to very weakly down-curved; the diameter of male ocellus longer than distance between lateral ocellus and eye; body length $5-8 \mathrm{~mm})$ T. genalis (Szépligeti, 1899)

- Malar space distinctly less than $2 \times$ as long as basal width of mandible .......3

3 Spurs on hind tibia unusually short, the longer spur shorter than apical width of hind tibia (body length $3.5 \mathrm{~mm}$; fore wing venation pigmented; the diameter of 


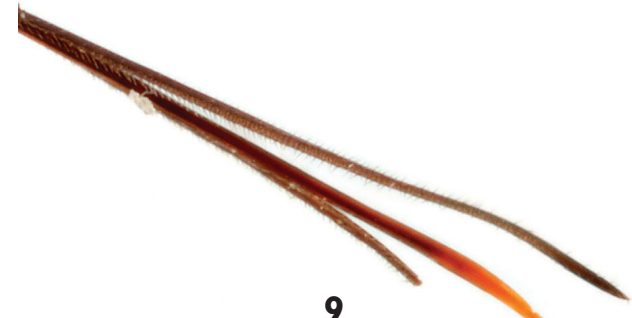

9

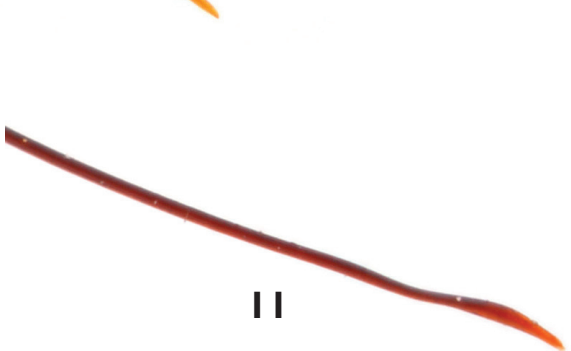

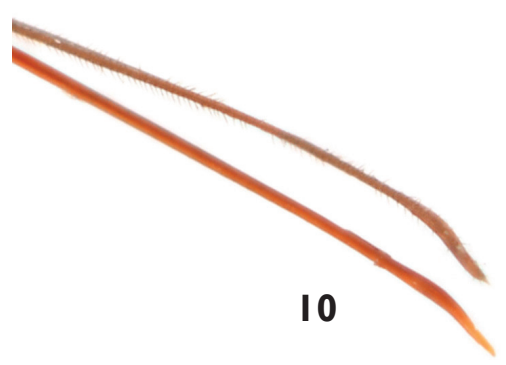

10

Figures 9-I I. Ovipositor apex characteristics, lateral view. 9 straight, Temelucha rea sp. n. 10 downcurved, Temelucha interruptor (Gravenhorst, 1829) II sinuous, Temelucha discoidalis (Szépligeti, 1899).

male ocellus almost as long as distance between lateral ocellus and eye) [female unknown] T. tibialis Kolarov, 1995

- $\quad$ Spurs on hind tibia not unusually short, longer spur is longer than apical width of hind tibia.........................................................................4

4 Fore wing venation partly unpigmented, basal abscissa of $M+C u$ spectral, other veins (except most apical ones) are more or less pigmented, not spectral; mesosoma predominantly black (ovipositor apex very weakly sinuous, not down-curved; male ocellus large, its diameter longer than distance between lateral ocellus and eye; body length 2.4-4 mm).... T. minuta (Morley, 1912)

- $\quad$ Fore wing venation pigmented, or if (partly) unpigmented, then pattern of depigmentation not the same as described above 5 Mesothorax in greater part yellow and/or reddish coloured (usually both female and male face mainly yellow; propodeum often with yellowish/reddish colouration)

- Mesothorax in greater part black (usually female face mainly dark, male face either mainly yellow or mainly dark; propodeum usually black)....

6 Frons with a pair of tubercles; hind femur elongate, $7.5 \times$ as long as wide medially (ovipositor apex straight with distinct dorsal subapical notch; fore wing $-6 \mathrm{~mm}$ long) [male unknown]

T. tuberculata Kolarov \& Beyarslan, 1999

- $\quad$ Frons without a pair of tubercles; hind femur not so elongate.....................7

$7 \quad$ Second discal cell $1.5-2 \times$ as long as first sub-discal cell ..........................8

- $\quad$ Second discal cell shorter, less than $1.5 \times$ as long as first sub-discal cell .....15 
All coxae entirely yellow and/or reddish (ovipositor apex down-curved; body length $7-8 \mathrm{~mm}$ ). T. schoenobia (Thomson, 1890)

- $\quad$ Propodeum long, not curved in lateral view

10 Male ocellus small, its diameter shorter than distance between lateral ocellus and eye; vein $2 m-c u$ weakly postfurcal (ovipositor sheath as long as fore wing from base to the base of marginal cell; ovipositor apex straight; body length 7-9 $\mathrm{mm}$ ) [the lightest specimens key out here, for the darker specimens see also couplet 47] T. lucida (Szépligeti, 1899)

Male ocellus large, the lateral one almost touching eye; vein $2 m$-cu interstitial (fore wing $6.3 \mathrm{~mm}$ long) [female unknown] .......T. ocellaris Kolarov, 1995 Fore wing vein $2 m-c u$ interstitial (female ocellus large, its diameter about the same as distance between lateral ocellus and eye; male ocellus large, its diameter longer than distance between lateral ocellus and eye; body length $6.5-7 \mathrm{~mm}$ ).... T. tricolorata Šedivý, 1968

Fore wing vein $2 m$-cu distinctly postfurcal (ocellus shorter than or about the same as distance between lateral ocellus and eye)

Following characters in combination: malar space $0.4 \times$ as long as basal width of mandible; inner eye orbits weakly convergent ventrally; ocellus small, its diameter shorter than distance between lateral ocellus and eye; fore wing -4 mm long [female unknown]

T. pagliani Kolarov, 1995

Not exactly as above (either female or male with distinctly longer malar space and parallel inner eye orbits, as in $T$. decorata (Gravenhorst, 1829), or with distinctly shorter fore wing, as in T. picticollis (Hellén, 1949))....

Propodeum black; ovipositor apex weakly sinuous; notaulus absent (male ocellus small, its diameter shorter than distance between lateral ocellus and eye; body length $4-5 \mathrm{~mm}$ ) [lighter female specimens key out here, for the darker females and males see also couplet 53 and 59]....

T. picticollis (Hellén, 1949)

Propodeum extensively yellowish/reddish coloured; ovipositor apex straight to very weakly down-curved; notaulus well developed. Female body 7-10 mm, fore wing 3.5-4 mm long; first tergite relatively stout, postpetiolus distinctly swollen (ovipositor sheath relatively shorter, less than $0.4 \times$ as long as body length; male ocellus relatively small, its diameter slightly shorter than or about the same as distance between lateral ocellus and eye; body length $6-10 \mathrm{~mm}$ )

T. decorata (Gravenhorst, 1829)

- $\quad$ Female body 4-5 $\mathrm{mm}$, fore wing less than $3 \mathrm{~mm}$ long; first tergite slender, postpetiolus not distinctly swollen (ovipositor sheath relatively longer, 0.4 or more $\times$ as long as body length) [male unknown] T. rea sp. n.

15 Body length 3-4 mm; fore wing venation mostly depigmented (ovipositor apex slightly down-curved) T. anatolica (Šedivý, 1968) 

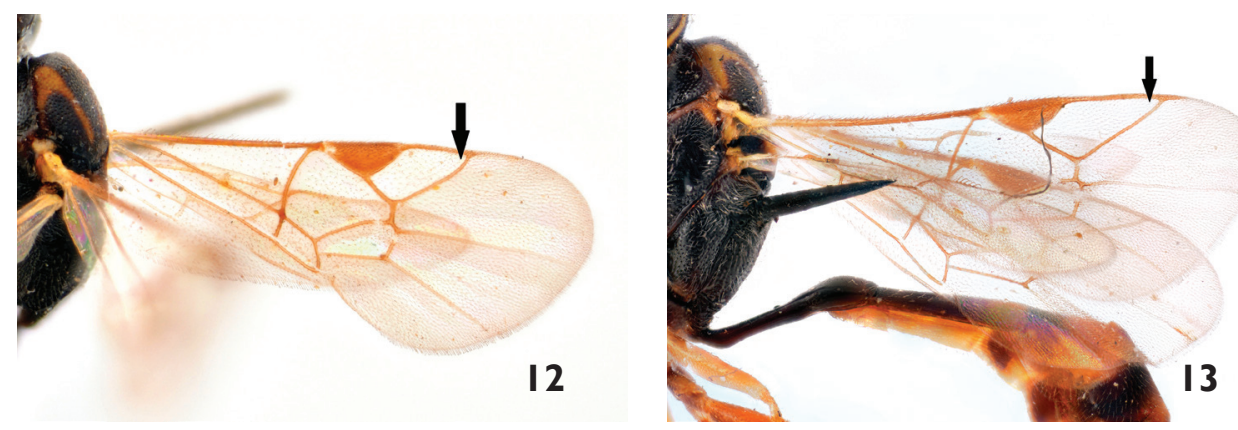

Figures 12-13. Fore wing characteristics. 12 Rs curved near the front margin of the wing, Temelucha signata (Holmgren, 1860) I3 Rs straight, not curved near the front margin of the wing, Temelucha interruptor (Gravenhorst, 1829).
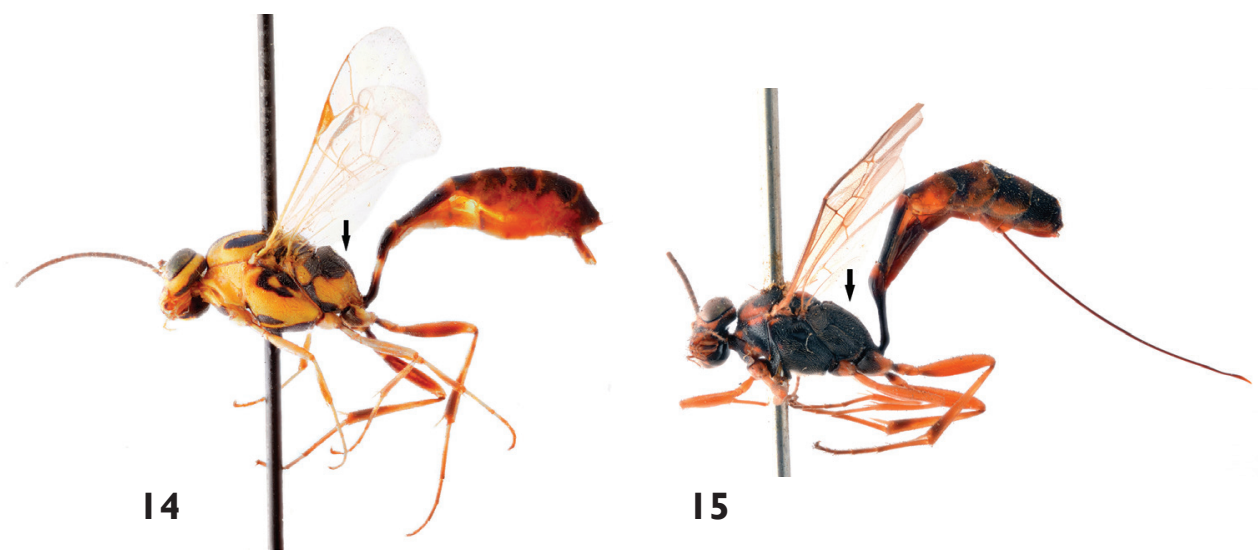

Figures 14-15. Propodeum characteristics, lateral view. I4 short and curved propodeum, Temelucha lucida (Szépligeti, 1899) I5 not short, not curved, 'usual' propodeum, Temelucha discoidalis (Szépligeti, 1899).

16 Ocellus small, its diameter as long as or shorter than the distance between lateral ocellus and eye (ovipositor sheath about as long as fore wing from base to the apex of marginal cell; body length $8-12 \mathrm{~mm}$ )

T. dorsonigra (Hedwig, 1957)

- Ocellus large, its diameter longer than the distance between lateral ocellus and eye

17 Hind tarsal claws distinctly longer than arolium; fifth tarsal segment of hind leg $4.2 \times$ as long as wide; ovipositor sheath about as long as fore wing (body length $\sim 10 \mathrm{~mm}$ ).

T. afghana Šedivý, 1968

- Hind tarsal claws as long as arolium; fifth tarsal segment of hind leg shorter, 3.2-3.4 $\times$ as long as wide; ovipositor sheath about as long as fore wing from base to the base of marginal cell (body length $8-11 \mathrm{~mm}$ )..... 
18 Front edge of clypeus almost straight to weakly convex; clypeus flat or very weakly convex in lateral view (cf. Fig. 16-17).

- $\quad$ Front edge of clypeus distinctly curved, convex; clypeus moderately to strongly convex in lateral view (cf. Fig. 18)

19 Ventral margins of first tergite not touching each other ..........................20

20 Mesosoma distinctly elongate, $2.6 \times$ as long as high, in lateral view slightly concave ventrally (ovipositor apex straight; male ocellus diameter shorter than distance between lateral ocellus and eye; fore wing length $2.5-2.7 \mathrm{~mm}$ )

T. cylindrator Narolsky, 1987

- $\quad$ Mesosoma not so elongate and not curved; fore wing > $4 \mathrm{~mm}$ long

21 Ovipositor sheath long, distinctly longer than fore wing (ovipositor apex weakly down-curved; male ocellus large, its diameter longer than the distance between lateral ocellus and eye; body length 9-11 mm)

T. caudata (Szépligeti, 1899)

- Ovipositor sheath distinctly shorter than fore wing (fore wing length 4.2 $\mathrm{mm}$ ) [male unknown]

T. pseudocaudata Kolarov, 1982

22 Malar space black (eye orbits mostly black, a pair of spots on the vertex and patches on the inner orbits below toruli are yellowish; ovipositor apex not down-curved; ovipositor sheath about as long as fore wing from base to the apex of marginal cell; diameter of male ocellus shorter than the distance between lateral ocellus and eye; body length 4-7 mm)

T. guttifer (Thomson, 1890)

- $\quad$ Malar space at least partly yellow, eye orbits partly or entirely yellow.......23

23 Fore wing with vein Rs almost straight, not curved near the front margin (cf. Fig. 13); ovipositor sheath as long as fore wing from base to apex of marginal cell (diameter of male ocellus shorter than the distance between lateral ocellus and eye; body length $-5 \mathrm{~mm}$ )

T. albipennis (Zetterstedt, 1838) Fore wing with $R s$ curved near the front margin of the wing (cf. Fig. 12)... 24 Ovipositor sheath as long as fore wing from base to base of marginal cell (the diameter of male ocellus shorter than the distance between lateral ocellus and eye; body length $5-9 \mathrm{~mm}$ ) T. signata (Holmgren, 1860)

- $\quad$ Ovipositor sheath longer, as long as fore wing or at least as long as fore wing from base to apex of marginal cell (body length $-5 \mathrm{~mm}$ ) [male unknown]....

T. subsignata Kolarov, 1989

25 Clypeus distinctly separated from face, strongly convex and nose-shaped in lateral view; propodeum convex in lateral view (ovipositor apex sinuous; male ocellus large, its diameter distinctly longer than the distance between lateral ocellus and eye; body length $6-8 \mathrm{~mm}$ ).

T. subnasuata (Thomson)

- $\quad$ Clypeus weakly separated from face, moderately convex and not nose-shaped in lateral view........................................................................ 26

26 Scutellum black (to a maximum brownish or rusty laterally)..................27

Scutellum entirely or partly yellow. 

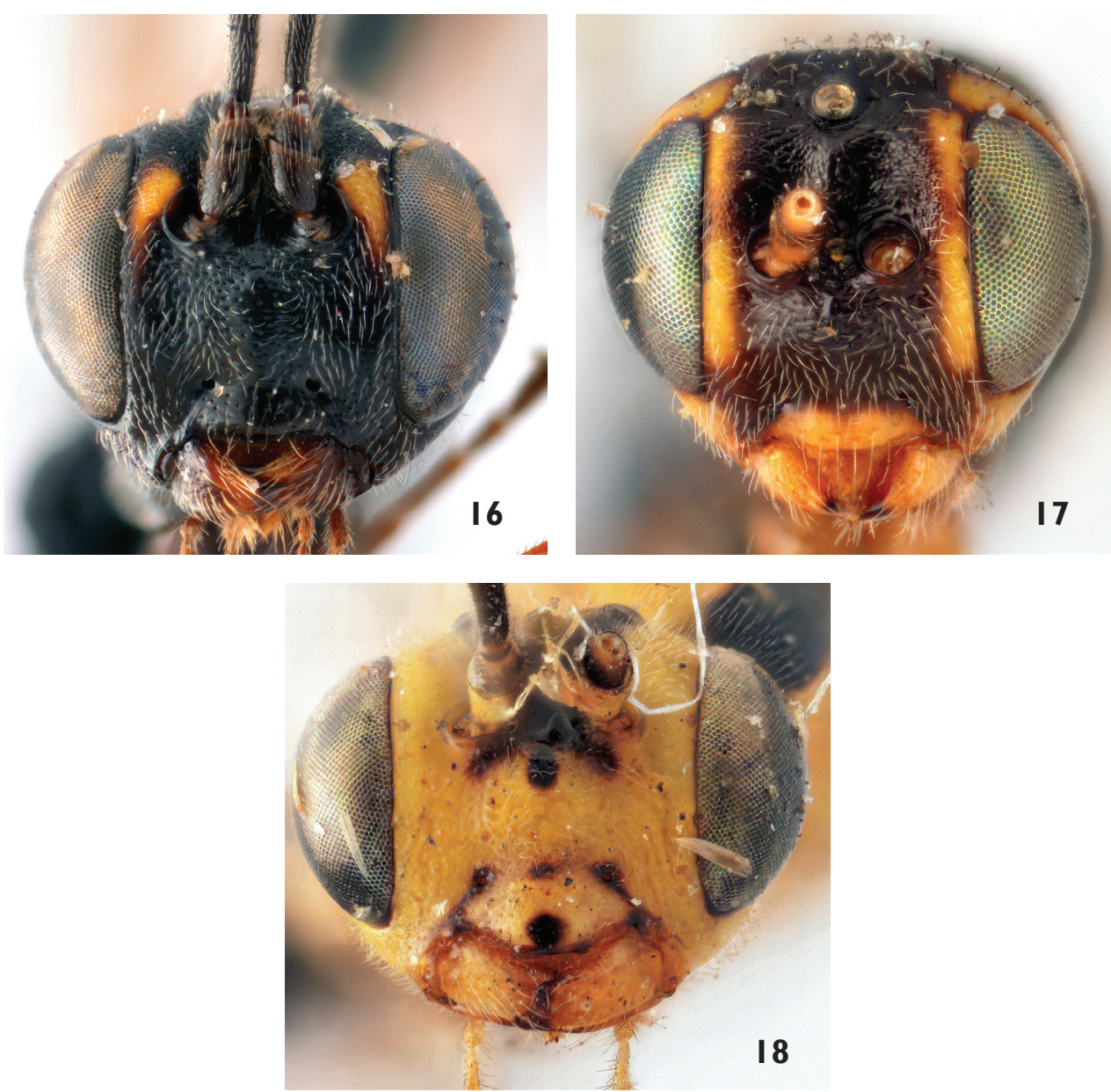

Figures 16-18. Clypeus characteristics, frontal view. 16 edge of clypeus almost straight, Temelucha caudata (Szépligeti, 1899) 17 edge of clypeus weakly convex, Temelucha signata (Holmgren, 1860) 18 edge of clypeus distinctly convex, Temelucha lucida (Szépligeti, 1899).

$27 \quad$ Frons raised laterally (ovipositor sheath as long as fore wing, ovipositor apex down-curved and with a distinct subapical notch; area superomedia closed from behind; the diameter of male ocellus as long as the distance between lateral ocellus and eye) T. turcata Kolarov \& Beyarslan, 1999

- $\quad$ Frons not raised laterally; ovipositor without dorsal subapical notch or with only a faint notch. 28

28 Following characters in combination: head large and transverse, gena strongly widened; second tergite coriaceous without longitudinal striation; area superomedia closed posteriorly; hind coxa relatively small (ovipositor longer than fore wing and with sinuous apex; the diameter of male ocellus shorter than 
the distance between lateral ocellus and eye; fore wing 4.4-4.9 mm long) .... T. tobiasi Narolsky, 2004

- $\quad$ Not exactly as above

29 Female [note that females of T. elongata Kolarov, 1995 and T. szepligetii (Dalla Torre, 1901) are unknown].

Male [note that male of T. thoracica Kolarov, 1989 is unknown]

30 Mesonotum short, only $1.1 \times$ as long as wide; ovipositor apex rather strongly down-curved (body length $\sim 7 \mathrm{~mm}$ )

T. thoracica Kolarov, 1989

Mesonotum more elongate; ovipositor apex either straight or sinuous, or very weakly down-curved

Malar space entirely or partly yellow

Malar space black to reddish

32 Scutellum without lateral carinae; malar space yellow (ovipositor apex straight; body length $4-5 \mathrm{~mm}$ )

T. tenerifensis Šedivý, 1993

Scutellum carinate to its apex; malar space only partly yellow (ovipositor apex straight to very weakly down-curved; body length $-5 \mathrm{~mm}$ ) [there are only a few females with partly yellow malar space; the majority have black malar space, hence they key out at couplet 35]

T. arenosa (Szépligeti, 1899)

Ovipositor apex not sinuous (straight or weakly down-curved)

Ovipositor apex sinuous.

Ovipositor sheath longer than fore wing (ovipositor apex straight and sharp; body length 6-7 $\mathrm{mm}$ ) T. longicauda Kolarov, 1996

Ovipositor sheath shorter than fore wing

Scutellum carinate to its apex (body length $-5 \mathrm{~mm}$ )

T. arenosa (Szépligeti, 1899)

Scutellum not carinate to its apex (body length 5-6.5 mm)

T. meridionellator Aubert, 1981

Scapus entirely dark brown (body length $7-8 \mathrm{~mm}$ ).

T. annulata (Szépligeti, 1899)

Scapus with yellow or reddish colouration

37 Thorax matt; propodeum elongate, not curved in lateral view; lateromedian carinae of first tergite reaching the middle of the tergite; petiolus basally depressed; outer surface of hind tibia brown (body length 5-6 mm).

T. ophthalmica (Holmgren, 1860)

Thorax shiny; propodeum short, curved in lateral view; lateromedian carinae of first tergite missing or faint; petiolus basally cylindrical; outer surface of hind tibia whitish (body length $\sim 7 \mathrm{~mm}$ )

T. marocator Aubert, 1977

Ocellus diameter longer than the distance between lateral ocellus and eye ... 39

Ocellus diameter shorter than the distance between lateral ocellus and eye......41

39 Scutellum without lateral carinae (body length $4-5 \mathrm{~mm}$ ).... 
40 Thorax matt; propodeum elongate, not curved in lateral view; outer surface of hind tibia brown (body length $5-6 \mathrm{~mm}$ )... T. ophthalmica (Holmgren, 1860) Thorax shiny; propodeum short, curved in lateral view; outer surface of hind tibia whitish (body length $-7 \mathrm{~mm}$ ) T. marocator Aubert, 1977 Malar space yellow.....

Malar space black to reddish

42 Fore wing veins indistinctly pigmented, pale yellowish, the wing membrane lactescent; scapus in greater part and ventral side of basal flagellomeres yellow (body length $-5 \mathrm{~mm}$ ). T. szepligetii (Dalla Torre, 1901) Fore wing veins pigmented, brown, the wing membrane more hyaline; scapus in greater part and ventral side of basal flagellomeres black or dark brown (body length $-5 \mathrm{~mm}$ )...... T. arenosa (Szépligeti, 1899) Propodeum short, curved in lateral view (body, except the legs, black; body length $6-7 \mathrm{~mm}$ ). T. longicauda Kolarov, 1996 Propodeum longer, not curved in lateral view Mesosoma elongate, $2.2 \times$ as long as high (fore wing $4.7 \mathrm{~mm}$ )

T. elongata Kolarov, 1995

Mesosoma not so elongate

Fore femur mainly yellowish/reddish (body length $\sim 7 \mathrm{~mm}$ )

T. annulata (Szépligeti)

Fore femur mainly black, anterior surface and apex yellowish or reddish (body length $5-6.5 \mathrm{~mm}$ ) [note that this couplet does not allow safe identification due to the poorly described males in the original description of this species]

T. meridionellator Aubert, 1981

Propodeum short, curved in lateral view (male ocellus small, its diameter shorter than distance between lateral ocellus and eye)

Propodeum long, not curved in lateral view (male ocellus either small or large)

47 Head and mesosoma not covered with unusually dense white hairs; vein $2 m$ $c u$ weakly postfurcal; ovipositor sheath relatively short, as long as fore wing from base to the base of marginal cell; ovipositor apex straight; usually mesoscutum, mesopleuron and propodeum with rich yellow colouration (body length 7-9 $\mathrm{mm}$ ) [for the lightest specimens see also couplet 10]

T. lucida (Szépligeti, 1899)

Head and mesosoma covered with distinct dense white hairs; vein $2 m$-cu postfurcal; ovipositor sheath distinctly longer; ovipositor apex weakly down-curved; body with more restricted yellow, propodeum black, mesopleuron only with small yellowish patch or black (body length $\sim 10 \mathrm{~mm}$ ).....

T. lucidator Kolarov, 1995

48 Following characters in combination: malar space swollen, $1.3 \times$ as long as basal width of mandible; notauli present as transversely striate shallow concavities; area superomedia pentagonal, closed posteriorly (ocellus diameter shorter than the distance between lateral ocellus and eye; body length -7 $\mathrm{mm}$ ) [female unknown] T. notaulata Kolarov, 1989 
- $\quad$ Not exactly as above

Female

Male [note that males of $T$. arenosella Kolarov, 1989, T. notata Kolarov, 1989, T. corsicator Aubert, 1961 are unknown]

51 Head very strongly and almost rectilinearly constricted behind eyes; hind femur reddish, usually somewhat darker basally (body length 6-9 $\mathrm{mm}$ )

T. interruptor (Gravenhorst, 1829)

Head strongly but roundly constricted behind eyes; hind femur yellowish apically (body length $-5 \mathrm{~mm}$ )

53 Ovipositor sheath as long as fore wing; body length 8-9 $\mathrm{mm}$; ovipositor apex strongly sinuous (head mainly black) T. discoidalis (Szépligeti, 1899) Ovipositor sheath distinctly shorter than fore wing; body length 4-5 mm; ovipositor apex weakly sinuous (head mainly yellow) [for lighter female specimens see also couplet 13] T. picticollis (Hellén, 1949) Following characters in combination: malar space slightly longer than basal width of mandible; second discal cell $2 \times$ as long as first sub-discal cell; area superomedia shiny with or without punctures; lateromedian carinae on first tergite short and weak or absent (body length 5-7 mm)

T. mohelnensis Šedivý, 1971

- $\quad$ Not exactly as above (malar space at a maximum as long as basal width of mandible; second discal cell less than $2 \times$ as long as first sub-discal cell; lateromedian carinae on first tergite usually distinct) ......

55 Following characters in combination: body length $-4.5 \mathrm{~mm}$; notauli absent or indistinct; first tergite as long as second tergite; lateromedian carinae on first tergite well developed

T. arenosella Kolarov, 1989

- $\quad$ Not exactly as above; body length 6-10 $\mathrm{mm}$ (first tergite either longer than second tergite, or if equal then notauli present).

56 Notauli present [although not very easy to recognize: the different sculpture (i.e. the very short transverse striae among the punctures of the mesoscutum) helps reveal the shallow line of the notaulus]; inner eye orbits slightly divergent ventrally; second discal cell distinctly longer $(-1.5-1.7 \times)$ than first sub-discal cell (area superomedia entirely or partly striate; body length $6-9 \mathrm{~mm}$ )

\section{T. variipes (Szépligeti, 1899)}

- $\quad$ Notauli absent or indistinct; inner eye orbits parallel; second discal cell less than $1.5 \times(-1.2 \times)$ as long as first sub-discal cell (area superomedia not entirely striate).

57 Head roundly constricted behind eyes; lateral areas of propodeum mainly striate; metasomal tergites brown to black, tergites 2-7 with lighter posterior edges (body length $\sim 10 \mathrm{~mm}$ ) T. confluens (Gravenhorst, 1829) 
- $\quad$ Head more strongly constricted behind eyes; lateral areas of propodeum mainly punctate; tergites black, only the apical tergites with lighter posterior edges (body length $\sim 10 \mathrm{~mm}$ )

T. corsicator Aubert, 1961

58 Ocellus diameter longer than the distance between lateral ocellus and eye (head, as in females, very strongly and almost rectilinearly constricted behind eyes; body length 6-9 $\mathrm{mm}$ )

T. interruptor (Gravenhorst, 1929)

- $\quad$ Ocellus diameter shorter than the distance between lateral ocellus and eye......59

59 Following characters in combination: body length $<5 \mathrm{~mm}$; second discal cell $\sim 1.5 \times$ as long as first sub-discal cell; lateromedian carinae of first tergite absent; pronotum and mesoscutum almost entirely black with little yellow colouration T. picticollis (Hellén, 1949)

- $\quad$ Not exactly as above; body length $>5 \mathrm{~mm}$

60 Second discal cell $2 \times$ as long as first sub-discal cell (area superomedia shiny with or without punctures; body length 5-7 mm) ...... T. mohelnensis Šedivý, 1971

- $\quad$ Second discal cell less than $2 \times$ as long as first sub-discal cell .....................61

61 Lateral areas of propodeum mainly striate; second discal cell less than $1.5 \times$ $(-1.2 \times)$ as long as first sub-discal cell (body length $\sim 8 \mathrm{~mm})$

T. confluens (Gravenhorst, 1829)

- $\quad$ Lateral areas of propodeum mainly punctate; second discal cell at least $\sim 1.5 \times$ as long as first sub-discal cell

62 Notauli present [although not very easy to recognize but usually easier than in females: the different sculpture (i.e. the very short transverse striae among the punctures of the mesoscutum) helps to reveal the shallow line of the notaulus]; inner eye orbits slightly divergent ventrally; area superomedia entirely or partly transversely striate (body length $6-8 \mathrm{~mm}$ )

T. variipes (Szépligeti, 1899)

- $\quad$ Notauli absent or indistinct; inner eye orbits parallel; area superomedia shiny and distinctly punctate, not striate (body length $8-9 \mathrm{~mm}$ ).....

T. discoidalis (Szépligeti, 1899)

\section{Acknowledgements}

I would like to express my gratitude to D. Mifsud (University of Malta, Msida) for donating the Maltese ichneumon wasp specimens to the HNHM Hymenoptera Collection and for his activity in our co-operation about the Maltese ichneumon wasp fauna, as well as to M. Zammit for collecting the specimens. I am especially grateful to G. R. Broad (Natural History Museum, London) for his valuable professional and linguistic corrections on the manuscript, as well as to J. A. Kolarov (University of Plovdiv, Plovdiv) and to an anonymous reviewer for their valuable comments. I thank S. A. Belokobylskij (Zoological Institute of the Russian Academy of Sciences, St. Petersburg), G. R. Broad (Natural History Museum, London), and J. Paukkunen (Finnish Museum of Natural History, Helsinki) for helping my work with relevant papers and/ 
or with borrowed type specimens. I am grateful to T. Németh (HNHM, Budapest) for the taking the photos and to Z. György (HNHM, Budapest) for post-processing some of them. This study was supported by Hungarian Scientific Research Fund (OTKA, Grant no. 108571).

\section{References}

Aubert JF (1977) Nouvelle série d'Ichneumonides pétiolées inédites. Bulletin de la Société Entomologique de Mulhouse 1977: 1-8.

Aubert JF (1981) Syllogismes, illogismes et innovations chez les Ichneumonides. Bulletin de la Société Entomologique de Mulhouse 1981: 17-22.

Gauld ID (1991) The Ichneumonidae of Costa Rica, 1. Introduction, keys to subfamilies, and keys to the species of the lower Pimpliform subfamilies Rhyssinae, Poemeniinae, Acaenitinae and Cylloceriinae. Memoirs of the American Entomological Institute 47: 1-589.

Gauld ID, Wahl D, Bradshaw K, Hanson P, Ward S (1997) The Ichneumonidae of Costa Rica, 2. Introduction and keys to species of the smaller subfamilies, Anomaloninae, Ctenopelmatinae, Diplazontinae, Lycorininae, Phrudinae, Tryphoninae (excluding Netelia) and Xoridinae, with an appendices on the Rhyssinae. Memoirs of the American Entomological Institute 57: 1-485.

Kolarov JA (1989) Taxonomic and faunistic study on Bulgarian Cremastinae (II) (Insecta, Hymenoptera, Apocrita: Ichneumonidae). Faunistische Abhandlungen 16: 149-154.

Kolarov JA (1995) Cremastinae (Hymenoptera, Ichneumonidae) from Italy and some adjacent regions. Linzer Biologische Beiträge 27(2): 1103-1114.

Kolarov JA (1996) A study of the Spanish Cremastinae (Hymenoptera, Ichneumonidae). Linzer Biologische Beiträge 28(2): 821-827.

Kolarov JA (1997) A review of the Cremastinae of the Balkan peninsula, Turkey and Cyprus with zoogeographical notes (Hymenoptera: Ichneumonidae). Beiträge zur Entomologie 47(1): 169-199.

Kolarov JA, Beyarslan A (1999) Beitrag zur Kenntnis der Turkischen Ichneumoniden 4. Cremastinae (Hymenoptera, Ichneumonidae). Entomofauna 20(1): 1-8.

Kolarov JA, Yurtcan M (2009) A study of the Cremastinae (Hymenoptera: Ichneumonidae) from Turkey. Turkish Journal of Zoology 33: 371-374. doi: 10.3906/zoo-0810-9

Narolsky NB (1987) [New species of the genus Temelucha (Hymenoptera, Ichneumonidae)]. [Fauna and Biocenotics Relations of the Ukranian Insects] Kiev, 46-48. [In Russian with English summary]

Narolsky NB (1990) On systematic position of some species of Ichneumonidae subfamily Cremastinae (Hymenoptera, Ichneumonidae). News of Faunistics and Systematics 1990: $128-133$.

Narolsky NB (2004) [A new species of the genus Temelucha Foerster and taxonomical remarks on the two Palaearctic species from subfamily Cremastinae (Hymenoptera: Ichneumonidae)]. Trudy Russkogo Entomologicheskogo Obshchestva 75(1): 39-42. [In Russian with English summary] 
Rousse P, Villemant C, Seyrig A (2011) Ichneumonid wasps from Madagascar. V. Ichneumonidae Cremastinae. Zootaxa 3118: 1-30. doi: 10.5852/ejt.2013.49

Schmiedeknecht O (1910) Opuscula Ichneumonologica. IV. Band. Fasc. XXIV-XXVI. Ophioninae. Blankenburg in Thüringen, 1841-2080.

Šedivý J (1971) Revision der europäischen Temelucha-Arten (Hym., Ichneumonidae). Acta scientiarum naturalium Academiae scientiarum bohemoslovacae, Brno 5(1): 1-34.

Šedivý J, Schwarz M (1993) Bemerkenswerte Cremastinae (Hymenoptera, Ichneumonidae) von den Kanarischen Inseln. Linzer Biologische Beiträge 25(1): 387-395.

Szépligeti Gy (1905) Übersicht der paläarktischen Ichneumoniden. I. Theil. Annales Musei Nationalis Hungarici 3: 508-540.

Townes H (1971) The genera of Ichneumonidae. Part 4. Memoirs of the American Entomological Institute 17: 1-372.

Yu DS, Horstmann K (1997) A catalogue of world Ichneumonidae (Hymenoptera). The American Entomological Institute, Gainesville, 1-1558.

Yu DS, van Achterberg C, Horstmann K (2012) Taxapad 2012 - World Ichneumonoidea 2011. Taxonomy, Biology, Morphology and Distribution. Ottawa, Ontario, Canada. www.taxapad.com 